\title{
KETAHANAN KULTIVAR BUAH TOMAT (Solanum lycopersicum L.) TERHADAP JAMUR Colletotrichum acutatum J. H. Simmonds PENYEBAB PENYAKIT ANTRAKNOSA
}

\author{
Aryani Refiliya' ${ }^{1}$, Yulianty ${ }^{1}$, Martha Lulus Lande ${ }^{1}$, Sri Wahyuningsih ${ }^{1}$ \\ ${ }^{1}$ Program Studi Biologi Murni, Jurusan Biologi, FMIPA, Universitas Lampung \\ [e-mailkorespodensi_:aryanirefi@gmail.com]
}

\begin{abstract}
Resistance of Tomato (Solanum lycopersicum L.) Cultivars Against Colletotrichum acutatum J. H. Simmonds Causes Anthracnose Disease. Tomatoes are annuals like chillies, egg plants and soon. One of the causes of decreased tomato productionis anthracnose disease caused by the fungus Colletotrichum acutatum. This study was conducted todetermine the resistance of tomatoes to anthracnose disease by the fungus Colletotrichum acutatum. This research was conducted at the Microbiology and Botany Laboratory, Department of Biology, Faculty of Mathematics and Natural Sciences, Lampung University in January to February 2020. This study uses a completely randomized design (CRD) with the treatment of tomatoes namely potpourri, bandung tomatoes, cherry tomatoes, and ordinary tomatoes using 6 replications. The parameters measured were the diameter of the spots of the Colletotrichum acutatum mushroom, occurrence of disease and the severity of anthracnose disease in each tomato, and the number of conidia of the Colletotrichum acutatum. The results showed that the small eroccurrence and severity of the disease were found in Bandung tomatoes while the smaller number of conidia was found in the potpourri.
\end{abstract}

Keywords: Anthracnose, Colletotrichumacutatum, Tomatoes

ABSTRAK : Ketahanan Kultivar Tomat (Solanum lycopersicum L.) Terhadap Jamur Colletotrichum acutatum J. H. Simmonds Penyebab Penyakit Antraknosa. Tomat merupakan tanaman semusim seperti halnya tanaman cabe, terong dan sebagainya. Salah satu penyebab menurunnya produksibuah tomat adalah penyakit antraknosa yang disebabkan oleh jamur Colletotrichumacutatum. Penelitian ini dilaksanakan untuk mengetahui ketahanan buah tomat terhadap serangan penyakit antraknosa oleh jamur Colletotrichumacutatum. Penelitian ini dilaksanakan di Laboratorium Mikrobiologi dan Laboratorium Botani, Jurusan Biologi, Fakultas Matematika dan Ilmu Pengetahuan Alam, Universitas Lampung pada bulan Januari sampai dengan Februari 2020. Penelitian ini menggunakan rancangan acak lengkap (RAL) dengan perlakuan buah tomat yaitu rampai, tomat bandung, tomat ceri, dan tomat biasa dengan menggunakan 6 ulangan. Parameter yang diukur yaitu diameter bercak jamur Colletotrichumacutatum, keterjadian penyakit dan keparahan penyakit antraknosa pada masing-masing buah tomat, serta jumlah konidia jamur Colletotrichumacutatum. Hasil penelitian menunjukkan bahwa keterjadian dan keparahan penyakit yang lebih kecil terdapat padatomatbandung sedangkan jumlah konidia yang lebih sedikit terdapat pada rampai.

Kata kunci: Antraknosa, Colletotrichumacutatum, Tomat 


\section{PENDAHULUAN}

Tomat (SolanumlycopersicumL.) adalah tumbuhan yang termasuk suku Solanacease, tumbuhan asli Amerika Tengah dan Selatan . Kata "tomat" berasal dari kata xitomate atau xitotomate dalam bahasa Aztek, dimana tomat merupakan keluarga dekat dari kentang (Sabiro, 2012).

Usaha pengembangan dan peningkatan produksi buah tomat tidak selalu berjalan mulus disebabkan banyak hambatan baik yang bersifat ekonomis, sosial, maupun biologis. Faktor biologis yang seringkali menjadi kendala adalah adanya serangan penyakit antraknosa yang di sebabkan oleh jamur Colletotrichum. Jamur dari marga Colletotrichummemiliki banyak jenis, 4 jenis dari Colletotrichum yaitu Colletotrichumgloeosporioides,

Colletotrichumcapsici,

Colletotrichumacutatum

Colletotrichumcoccodes

dan 2004).

Beberapa tanaman diketahui mempunyai ketahanan yang berbedabeda terhadap penyakit yang disebabkan oleh Colletotrichumacutatum. Pengujian ketahanan terhadap penyakit diukur berdasarkan kejadian atau insiden penyakitnya. Semakin besar kejadian atau insiden penyakitnya maka semakin rentan suatu varietas terhadap suatu penyakit, sebaliknya semakin kecil kejadian penyakit maka semakin tahan varietas tersebut. Kejadian penyakit sangat baik untuk dijadikan referensi dari sisi ekonomi karena memperhitungkan seberapa besar kehilangan buah dari serangan antraknosa (Gultom, 2005).

Berdasarkan uraian dari latar belakang tersebut perlu dilakukan penelitian tentang ketahanan buah tomat terhadap serangan jamur colletotrichumacutatum Penyebab penyakit antraknosa. Penelitian ini dilaksanakan untuk mengetahui ketahanan kultivar buah tomat terhadap serangan penyakit antraknosa yang disebabkan oleh jamur Colletotrichumacutatum.

\section{METODOLOGI PENELITIAN}

Alat-alat yang digunakan pada penelitian ini antara lain tisue, plastik wrap, jarum suntik dan spoit $10 \mathrm{cc}$, wadah plastik, penggaris, batang pengaduk, labu erlenmayer, sumbat kapas, alumuniumfoil, neraca analitik, autoklaf, cawan petri, tabung reaksi, ose, vorteks mixer, pipet volumetric,haemocytometer, bunsen, kertas label, kertas, buku dan alat tulis, serta kamera untuk dokumentasi. Bahan-bahan yang digunakan antara lain buah tomat, alkohol 70\%, 19,5 grPotatoDextrose Agar (PDA), $2000 \mathrm{ml}$ aquades, cabai yang terinfeksi jamur Colletotrichumsp.

\section{Pembuatan} PotatoDextrose Agar (PDA)

Membuat media PotatoDextrose Agar (PDA) sebagai media isolasi dan pembiakan jamur Colletotrichumacutatum. Dimasukan $19,5 \mathrm{~g}$ PDA kedalam beakerglass, kemudian dimasukanaquades sebanyak $500 \mathrm{ml}$, stirrer dan panaskan hingga terjadi perubahan warna menjadi lebih jernih. Kemudian media disterilkan menggunakan autoklaf selama 15 menit suhu $121{ }^{\circ} \mathrm{C}$ dan tekanan 2 atm. Jika tekanan autoklaf sudah turun, mediadikeluarkan dan ditunggu hingga menjadi suhu ruang. Kemudian mediadiberi antibiotik $1 / 4$ bagian, dihomogenkan dan dituang ke cawan steril. Setelah media padat dapat langsung digunakan.

\section{Biakan Murni Jamur} Colletotrichumsp

Pembuatan biakan murni jamur Colletotrichumsp. dengan mengunakan buah cabai yang terkena antraknosa diambil dari pasar Jati mulyo, Jati agung, Lampung Selatan kemudian langsung dimasukkan ke dalam plastik, diberi label tanggal, lokasi dan nama kolektor. Di Laboratorium, permukaan buah cabai disterilisasi dengan alkohol. 
Setelah kering antara bagian yang sakit dan sehat dipotong $1 / 2 \mathrm{~cm} \mathrm{x}$ $1 / 2 \mathrm{~cm}$. Kemudian potongan cabai diletakkan dalam cawan petri yang telah berisi media PDA. Jamur yang tumbuh pada media PDA diisolasi dan sehingga didapatkan isolat jamur Colletotrichumacutatum. Isolat kemudian dipindahkan dalam tabung reaksi yang berisi media PDA dan diberi label (nama, tanggal, dan asal jamur). Jamur tersebut diinkubasi selama 5 hari pada suhu $30^{\circ} \mathrm{C}$. Kemudian jamur tersebut diidentifikasi sampai ditemukan

Colletorichumacutatum.

\section{Pembuatan Suspensi Konidia Jamur}

Membuat suspensi konidia jamur menggunakan jamur yang telah ditumbuhkan pada media PDA yang berumur 5 hari diambil sebanyak 1 ose, dan dimasukkan ke dalam tabung reaksi yang berisi $10 \mathrm{ml}$ aquades steril. Kemudian dihomogenkan dengan vorteks mixer selama beberapa menit. Suspensi jamur kemudian diambil dengan pipet volumetri. Selanjutnya dilakukan pengenceran sehingga diperoleh kepadatan konidia jamur $1,8 \times 10^{5}$, dilakukan berulang-ulang sehingga diperoleh stok suspensi konidia.

\section{Perlakuan Pada Buah Tomat}

Permukaan buah tomat disterilkan menggunakan alkohol $70 \%$ kemudian dilukai dengan disuntik menggunakan jarum steril, dan diinokulasi dengan $100 \mu \mathrm{l}$ jamur Colletotrichumsp. dari suspensi konidia (105 konidia /200 m). Buah-buah tomat itu kemudian diinkubasi dalam wadah plastik pada suhu $25^{\circ} \mathrm{C}$ dengan kelembaban relatif lebih dari $95 \%$.

\section{Parameter Pengamatan}

Pengamatan dilakukan sampai dengan hari ke 8 setelah aplikasi pada buah tomat yang berbeda. Insiden penyakit atau keterjadian penyakit merupakan persentase jumlah tanaman yang terserang patogen $(n)$ dari total tanaman yang diamati (N) tanpa melihat tingkat keparahan penyakitnya (Aldila, 2010). Keterjadian penyakit dihitung dengan rumus sebagai berikut:

Keterjadian Penyakit $=\frac{n}{N} \times 100 \%$

Keterangan :

$\mathrm{n}=$ Buah terserang

$\mathrm{N}=$ Jumlah buah total Intensitas penyakit atau keparahan penyakit merupakan proporsi luas permukaan inang yang terinfeksi terhadap total luas permukaan inang yang diamati. Pengamatan intensitas penyakit dilakukan insitu secara visual. Rumus untuk menghitung keparahan penyakit adalah sebagai berikut:

$$
K P=\frac{\sum(n x v)}{N x V} 100 \%
$$

$$
\begin{aligned}
\mathrm{KP} & =\text { Keparahan penyakit (\%) } \\
\mathrm{n} & =\text { Banyaknya buah tomat dalam } \\
& \text { setiap kategori serangan } \\
\mathrm{N} & =\begin{array}{l}
\text { Jumlah buah tomat yang } \\
\text { diamati }
\end{array} \\
\mathrm{v} \quad= & \text { Nilai numerik untuk tiap } \\
& \text { kategori serangan } \\
\mathrm{V} \quad= & \text { Nilai skor tertinggi }
\end{aligned}
$$

Skor penyakit yang digunakan adalah sebagai berikut :

Skor penyakit 0 ; Tidak ada infeksi

Skor penyakit 1 ; Luas permukaan buah tomat atau bagian buah tomat yang terserang $1 \%$ sampai $25 \%$

Skor Penyakit 2 ; Luas permukaan buah tomat atau bagian buah tomat yang terserang lebih besar dari $26 \%$ sampai $50 \%$.

Skor penyakit 3 ; Luas permukaan buah tomat atau bagian buah tomat yang terserang lebih besar dari $51 \%$ sampai $75 \%$.

Skor penyakit 4 ; Luas permukaan buah tomat atau bagian buah tomat yang terserang lebih besar dari $75 \%$.

Data kuantitatif yang diperoleh dari setiap variabel dihomogenken dengan uji bartlets kemudian dianalisis dengan menggunakan uji Beda Nyata Terkecil (BNT) pada taraf nyata $5 \%$. 
HASIL PENELITIAN

\section{Diameter Koloni Colletotrichumacutatum}

Gejala penyakit antraknosa mulai terlihat sejak hari ke 3 setelah dilakukan perlakuan. Pada hari ke 8 gejala antraknosa semakin menunjukan peningkatan dengan bertambahnya diameter permukaan buah tomat yang diinfeksi jamur Colletotrichumacutatum.

Berdasarkan hasil uji analisis ragam didapatkan bahwa nilai $F$ hitung dari diameter penyakit antraknosa pada buah tomat pada hari ke 6 dan 8 lebih kecil dari pada nilai nilai $F$ tabel $0,05 \quad(3,098)$. Hal ini menunjukkan bahwa perlakuan pada buah tomat yang diinokulasi jamur Colletotrichumacutatum tidak menimbulkan pengaruh terhadap diameter bercak jamur. Karena tidak ada perbedaan yang signifikan maka tidak dilakukan uji lanjut BNT 5\%.

Tabel 1. Rerata diameter bercak jamur Colletotrichumacutatum di permukaan buah tomat $(\mathrm{cm})$ pada hari ke-6 dan ke-8

\begin{tabular}{|c|c|c|c|c|c|c|}
\hline \multirow[t]{2}{*}{ Jenis Tomat } & \multicolumn{3}{|c|}{$\begin{array}{c}\text { Hari ke- } \\
6 \\
\end{array}$} & \multicolumn{3}{|c|}{$\begin{array}{c}\text { Hari ke- } \\
8 \\
\end{array}$} \\
\hline & $\mu$ & \pm & SD & $\mu$ & \pm & SD \\
\hline Rampai & 0,556 & \pm & 0,3318 & 0,678 & \pm & 0,3981 \\
\hline Tomat & & \pm & & & \pm & \\
\hline Bandung & 0,561 & & 0,3750 & 0,794 & & 0,4950 \\
\hline Tomat Ceri & 0,433 & \pm & 0,3406 & 0,506 & \pm & 0,3726 \\
\hline Tomat Biasa & 0,550 & \pm & 0,3650 & 0,939 & \pm & 0,5192 \\
\hline
\end{tabular}

\section{Keterjadian Penyakit Antraknosa}

Hasil penelitian menujukan bahwa buah tomat memiliki persentase keterjadian penyakit antraknosa yang berbeda nyata pada setiap kultivar. Setelah dilakukan uji BNT pada taraf $5 \%$ hasilnya adalah sebagai berikut:

Tabel 3. Keterjadian penyakit antraknosa buah tomat pada hari ke-6 dan ke-8

\begin{tabular}{|c|c|c|c|c|c|c|c|c|}
\hline & \multicolumn{4}{|c|}{ Hari ke-6 } & \multicolumn{4}{|c|}{ Hari ke-8 } \\
\hline Jenis tomat & $\mu$ & \pm & SD & $\begin{array}{c}\text { Sig } \\
0,05\end{array}$ & $\mu$ & \pm & SD & $\frac{\text { Sig }}{0,05}$ \\
\hline Rampai & 94,444 & \pm & 13,6083 & $A$ & 94,444 & \pm & 13,6083 & $a$ \\
\hline Tomat & & \pm & & B & & \pm & & c \\
\hline Bandung & 50,000 & & 34,9603 & & 55,556 & & 27,2166 & \\
\hline Tomat Ceri & 55,556 & \pm & 34,4265 & B & 61,111 & \pm & 38,9682 & bc \\
\hline Tomat Biasa & 66,667 & \pm & 36,5148 & $a b$ & 88,889 & \pm & 17,2133 & $a b$ \\
\hline Keterangan: & $\begin{array}{l}=\text { rata-r } \\
=\text { Stand } \\
=\text { Signif }\end{array}$ & & & & & & & \\
\hline
\end{tabular}

Berdasarkan hasil uji analisis ragam pada hari ke-6 dan ke-8 didapatkan bahwa nilai $F$ hitung dari insiden penyakit antraknosa pada buah tomat lebih kecil dari pada nilai nilai $\mathrm{F}$ tabel $0,05 \quad(3,098)$. Hal ini menunjukkan bahwa terdapat perbedaan yang nyata pada keterjadian penyakit antraknosa hari ke-6 dan ke8. Hari ke-6 Rampai memiliki perbedaan yang nyata dengan tomat bandung dan tomat ceri. Sedangkan tomat biasa tidak memiliki perbedaan yang nyata dengan tomat bandung, rampai maupun tomat ceri. 
Namun pada hari ke-8 rampai memiliki perbedaan keterjadian penyakit dengan tomat bandung dan tomat ceri. Tomat bandung memiliki perbedaan keterjadian penyakit dengan rampai dan tomat biasa. Tomat ceri hanya memiliki perbedaan keterjadian penyakit dengan rampai. Dan tomat biasa hanya memiliki perbedaan keterjadian penyakit dengan tomat bandung. Keterjadian penyakit tidak dipengaruhi oleh keparahan penyakitnya. Karena keterjadian penyakit dihitung berdasarkan jumlah keseluruhan tomat yang terinfeksi dalam satu wadah yang diamati.

\section{KeparahanPenyakit Antraknosa}

Hasil penelitian menunjukkan bahwa buah tomat memiliki interaksi yang berbeda nyata dengan jamur Colletotrichumacutatum. Setelah dilakukan uji BNT pada taraf 5\% hasilnya adalah sebagai berikut:

Tabel 6.Keparahan penyakit antraknosa buah tomat pada pengamatan hari ke-6 dan ke-8

\begin{tabular}{|c|c|c|c|c|c|c|c|c|}
\hline Jenis Tomat & $\mu$ & \pm & SD & $\frac{\text { Sig }}{0,05}$ & $\mu$ & \pm & SD & $\frac{\text { Sig }}{0,05}$ \\
\hline Rampai & 63,275 & \pm & 14,5014 & $a$ & 63,275 & \pm & 14,5014 & $a$ \\
\hline Tomat & & \pm & & c & & \pm & & $b$ \\
\hline Bandung & 9,942 & & 6,9625 & & 12,218 & & 7,9124 & \\
\hline Tomat Ceri & 27,775 & \pm & 20,4035 & b & 25,552 & \pm & 18,0956 & $b$ \\
\hline Tomat Biasa & 13,387 & \pm & 7,2456 & bc & 18,943 & \pm & 5,1240 & b \\
\hline Keterangan: $\mu$ & $\begin{array}{l}=\text { rata-ro } \\
=\text { Stand } \\
=\text { Signif }\end{array}$ & & ata) & & & & & \\
\hline
\end{tabular}

Berdasarkan analisis ragam didapatkan bahwa nilai $F$ hitung dari keparahan penyakit antraknosa pada buah tomat lebih besar dari pada nilai nilai $F$ tabel $0,05(3,098)$, hal tersebut menunjukkan bahwa terdapat perbedaan yang signifikan antara intensitas penyakit antraknosa masingmasing kultivar buah tomat. Hari ke-6 Rampai memiliki perbedaan yang nyata dengan tomat bandung, tomat ceri dan tomat biasa. Tomat bandung memiliki perbedaan dengan rampai dan tomat ceri. Tomat ceri memiliki perbedaan dengan rampai dan tomat bandung. Sedangkan tomat biasa hanya memiliki perbedaan dengan rampai. Namun pada hari ke-8 Rampai memiliki perbedaan keparahan yang nyata dengan tomat bandung, tomat ceri dan tomat biasa. Sedangkan tomat bandung, tomat ceri dan tomat biasa tidak menunjukkan perbedaan yang nyata.

\section{Jumlah Konidia}

Analisis ini dilakukan untuk mengetahui jumlah konidia yang terdapat pada buah tomat yang terserang penyakit antraknosa disajikan pada tabel 7.

Tabel 7. Rerata jumlah konidia jamur Colletotrichumacutatum penyebab penyakit antraknosa pada buah tomat

\begin{tabular}{ccccc}
\hline Jenis tomat & $\mu$ & \pm & SD & Sig \\
\hline Rampai & 4,782 & \pm & 0,2368 & 0,05 \\
Tomat & & \pm & & $\mathrm{c}$ \\
Bandung & 7,361 & & 0,5790 & \\
Tomat Ceri & 5,687 & \pm & 0,2199 & $\mathrm{~b}$ \\
Tomat Biasa & 7,224 & \pm & 0,5299 & $\mathrm{a}$ \\
\hline Keterangan: $\mu=$ rata-rata & & & \\
& SD $=$ Standard Deviasi \\
Sig = Signifikan (beda nyata) & & &
\end{tabular}


Berdasarkan analisis ragam didapatkan bahwa nilai $\mathrm{F}$ hitung dari jumlah konidia jamur Colletotrichumacutatum pada buah tomat lebih besar dari pada nilai nilai $F$ tabel 0,05 $(3,098)$, hal tersebut menunjukkan bahwa terdapat perbedaan yang signifikan antara pertumbuhan konidia pada masingmasing kultivar tomat. Rampai memiliki perbedaan yang nyata dengan tomat bandung, tomat ceri dan tomat biasa. Pada jumlah konidia tomat bandung dan tomat biasa tidak ada perbedaan yang nyata namun keduanya memiliki perbedaan yang nyata dengan rampai dan tomat ceri. Sedangkan tomat cerimemilki perbedaan jumlah konidia yang nyata dengan rampai, tomat bandung maupun tomat biasa. Pada penelitian ini jumlah konidia tidak mengalami perkembangan karena konidia belum pada tahap reproduksi.

\section{PEMBAHASAN}

Tomat merupakan salah satu jenis buah yang memiliki senyawa polifenol yang sebagian besar terdiri dari flavonoid dan fenol. (Eveline, 2014). Beberapa senyawa fenol telah diketahui fungsinya. Misalnya lignin sebagai pembentuk dinding sel dan antosianin sebagai pigmen. Senyawa fenol mempunyai aktivitas antioksidan, antitumor, antiviral, dan antibiotik.

Senyawa dan enzim seperti fenol, protein dan poligalakturonase terkandung dalam tomat (Schlosser, 1980dalamSumaraw, 1999).

Oswald dan Tampubolon (1981) mengemukakan bahwa senyawa fenol dapat bersifat desinfektan, dan dapat masuk ke dalam tubuh jamur dan mengganggu terbentuknya sel baru. Terganggunya pembelahan sel menyebabkan pertumbuhan jamur menjadi abnormal. Selain itu senyawa ini dapat menyebabkan terhambat nyasporulasidimana pertumbuhan jamur dan konidiofor menjadi lambat sehingga pembentukan konidia terganggu. Pengujian ketahanan terhadap penyakit diamati diukur berdasarkan keterjadian atau insiden penyakitnya. Semakin besar keterjadian atau insiden penyakitnya maka semakin rentan suatu kultivar terhadap suatu penyakit, sebaliknya semakin kecil kejadian penyakit maka semakin tahan kultivar tersebut. Menurut Gultom (2005) keterjadian penyakit sangat baik untuk dijadikan referensi dari sisi ekonomi karena memperhitungkan seberapa besar kehilangan buah dari serangan antraknosa. Sastrosumardjo (2003) menambahkan bahwa kejadian penyakit menunjukkan parameter terbaik untuk dijadikan tolak ukur klasifikasi tingkat ketahanan.

Tingginya tingkat keparahan penyakit pada buah tomat salah satunya disebabkan oleh kurangnya aktivitas fitoaleksin. Karena semakin tinggi aktivitas fitoaleksin maka semakin dapat mencegah perkembangan jamur pada buah tomat. Rampai mempunyai keparahan penyakit yang tinggi karena pada saat infeksi jamur tidak hanya terjadi di permukaan saja namun masuk hingga ke dalam daging buah sehingga menyebabkan kurangnya produksi fitoeleksin pada rampai.

Besarnya diameter bercak mempengaruhi banyaknya jumlah konidia pada buah tomat. Tomat bandung dan tomat biasa mempunyai ukuran yang lebih besar daripada tomat ceri dan rampai sehingga ukuran diameter bercak tomat bandung dan tomat biasa lebih besar. Sehingga jumlah konidia pada tomat bandung dan tomat biasa lebih banyak daripada tomat ceri dan rampai.

Perbedaan ukuran dan struktur kulit pada masing-masing buah tomat maka pertumbuhan jamur Colletotrichumacutatum juga berbeda. Tanaman yang tahan terhadap infeksi mikroorganisme akan menunjukkan adanya peningkatan aktivitas enzim peroksidase, sedangkan pada tanaman yang rentan infeksi akan menunjukkan penurunan aktivitas enzim peroksidase (Agrios, 1996). Enzim peroksidase juga berperan 
sebagai katalisator dalam proses pembentukan lignin (Bouizgarne dkk., 2006).

Dengan adanya lignin maka dinding sel tumbuhan menjadi lebih tebal sehingga sulit dipenetrasi jamur. Lignin merupakan sistem ketahanan struktur tanaman yang memiliki sifat sukar terdegradasi oleh mikroorganisme. Berfungsi untuk menghambat patogen masuk dan berkembang pada jaringan tanaman (Sticher dkk., 1997; Lea dan Leegood, 1999).

\section{KESIMPULAN}

Kesimpulan yang diperoleh dari hasil penelitian ini adalahketerjadian dan keparahan penyakit yang lebih kecil terdapat pada tomat bandung. Sedangkan jumlah konidia yang lebih sedikit terdapat pada rampai.

\section{DAFTAR PUSTAKA}

Agrios, G.N. 1996. Ilmu Penyakit Tumbuhan. Gadjah Mada UniversityPress. Yogyakarta.

Aldila. 2010. Kejadian dan keparahan penyakit di kebun percobaan. http://aldila.r08.student.ipb.ac.i d. Diakses pada 16 februari 2020.

AVRDC.

2004

Evaluationofphenotypicandmolec ularcriteriaforthe

IdentificationofColletotrichumsp eciescausingpepperanthracnose in Taiwan. AVRDC Report 2003. AVRDC, Shanhua, Taiwan.

Bouizgarne, B., Bouteau, H.E.M., Frankart, C., Reboutier, D., Madiona, K.,Pennarun, A.M., Monesriez, M., Trouverre, J., andHadrami, E.I. 2006. Early Physiological Respons ofArabidopsisThalianaCelltoFusar icAcidToxicandSignallingEffects.

New Phytologist. 169 : 209-218.
Eveline, T.M. Siregar dan Sanny. 2014. Studi aktivitas antioksidan pada tomat (Lycopersiconesculentum) konvensional dan organik selama penyimpanan. Prosiding Seminat Nasional Sains dan Teknologi. 5: 22-28.

Gultom, A. 2005. Keragaan 13 Genotipe Cabai (Capsicumsp.) dan Ketahanannya Terhadap Penyakit Antraknosa yang Disebabkan Oleh Colletotrichumgloeosporioides (Penz.). Departemen Agronomi dan Hortikultura.Fakultas Pertanian. IPB. Bogor. $41 \mathrm{hlm}$.

Lea,P. andLeegood R.C. 1999. PlantBiocemistryandmoleculerBi ology. 2nd ed. John Wiley\& Sons Ltd. Chichester.

Tampubolon, Oswald T, 1981. Tumbuhan Obat Bagi Pecinta Alam.Bhratara Karya Aksara. Jakarta

Sabiro, Achmad 2013. Mengenal Lebih Jauh Tomat. http://www.scribd.com/doc/378 46069/Makalah-TOMAT Diakses pada 19 september 2019.

Sastrosumarjo, S. 2003. Pembentukan varietas cabai tahan penyakit antraknosa dengan pendekatan metode convensional dan bioteknologi.Kementrian Reset dan Teknologi RI LIPI. Jakarta.

Sumaraw, SM. 1999. Periode kritis tanaman tomatterhadap serangan Allernariasolani (Ell.\& G. Martin) Sor. dan faktor penentunya.Buletin Hama dan Penyakit Tumbuhan.11 (2): 67-72.

Sticher L., Mauch Mani, B., andMetraux, J.P., 1997. SystemicAcauiredResistance. AnnualReviemPhytopathology. 35: 235-270. 